\title{
Socializing Higher Education in a Number of Asian Countries and Lessons for Vietnam from a Philosophical Perspective
}

\author{
Truong Thi Thanh Quy ${ }^{*}$, Duong Nhan ${ }^{2}$ \\ ${ }^{l}$ Hanoi Medical University, Vietnam \\ ${ }^{2}$ Thainguyen University of Technology, Vietnam
}

*Corresponding Author: Truong Thi Thanh Quy, Hanoi Medical University, Vietnam

\begin{abstract}
Promotion of socialization for educational service in general and higher educational service in particular (from university and up) in Vietnam is a process to mobilize the physical and intellectual resources of society in order to participate in education career development. Building a responsible community of all people classes for creating a favorable environment for educational activities is a major policy of the Party and State of Vietnam. This study carries out survey in a number of Asian countries (Japan, Singapo) that have made a lot of achievements in the educational socialization from a philosophical perspective in order to draw some suggestions for the process of higher education socialization in Vietnam.
\end{abstract}

Keywords: Socializing Higher Education, Japan, Singapo, Vietnam

\section{INTRODUCTION}

In recent years, in Vietnam, the system of non-public higher education service providers has been growing, which meets the significant needs of the society. The network of universities and training institutes have been expanded, the proportion of students in private schools is increasing, etc. However, in reality, the socialization of higher education has not yet ensured the orientation planned, the result of implementation is not commensurate with the potential and unstable. The mechanisms, investment policies, attraction of social resources to develop non-public higher education institutions are not strong enough; the policies of economic leverage such as tax, credit, land, salary regime, social insurance, etc. have not been implemented. The organization of the state is still lax, the direction for lack of determination among ministries, departments, branches and localities is not close. Therefore, researching experiences of countries with high achievements in the development of education in general and the higher education socialization in general to draw the useful experiences for Vietnam in promoting the socialization of higher education is anurgent issue in practice and theory. In this study, we choose two Asian countries including Singapore and Japan, because the educational achievements of these two countries are highly appreciated and they can bring useful experiences for Vietnam.

\section{METHODS}

In this article, we use common research methods such as: logical, historical, analytical and general methods. In addition, we also use interdisciplinary methods such as statistics, comparative. In this article, we also use some data and results in the research works of some other authors to find solutions in the process of educational socialization in Vietnam today.

\section{RESUltS}

\subsection{Socialization of Higher Education in Singapore}

Singapore education gets high quality and is prestigious in the region, attracting many students from abroad to study. This is rooted in an education development strategy suitable to the country's conditions with a significant investment (about $4 \%$ of the national budget) for the education sector [NguyenMinhphuong, 2012; p.125].

Implementing the training strategy to meet the needs of economic development, Singapore also pays great attention to technical and vocational training such as combining with big companies and 
organizing the vocational courses lasting from 3 to 4 years; cooperating with multinational companies in Singapore to open the training centers with the method that the Government provides finance and infrastructure, the companies undertake the construction, management and curriculum development. At the same time, the Government has also issued a number of policies to encourage the companies to organize the vocational training courses for their staffs and employees during the working process. On-the-job training strategies include: building on-the-job training models at large companies and then applying them to small companies in the same field; training 100 consultants to supportthe companies to establish and operate on-the-job training models, etc. [NguyenVanManh, 2012; p.130]

Singapore conducts diversification of training services so that the learners can select appropriate training institutions and majors. Currently, Singapore has more than 300 private schools providing training in the multiple majorsincluding business administration, information technology, tourism, commerce, arts, languages, etc. In addition, there are more than 10 world-famous universities and academies for training quality located the training institutions in Singapore in order to serve the students from other countries to study such as: Korea; Vietnam, Philipin... [Nguyen Minh Phuong, 2012; p.136]

In order to ensure the training quality and increase the confidence of foreign students while attending the private schools, Singapore has implemented the Castrut Certificate issuance regime for the private schools. This is a certificate of the Consumers Association of Singapore specifically for the education sector, whereby, the schools must have clear tuition and fee compensation policies; strictly implementing the school's commitments on minimum welfare and quality of training for international students. In addition, Singapore's leading quality private schools must ensure good management and high quality in training.

\subsection{Socialization of Higher Education in Japan}

For higher education system, redefining the role of universities and colleges in the direction of increasing the integration of educational and research functions. On that basis, implementing diversification ofstudying opportunities and flexibility of studying forms; promotingthe research cooperation between universities and production and business establishments; forming training programs jointly developed by universities and enterprises to retrain theemployees, recognizing studying and research environment outside the school; organizing local student volunteer teams so that students can have career-oriented early [Vietnam Academy of Educational Sciences, 2008, p.15].

The law on promoting technology transfer of Japan plays an important role in promoting the close cooperation between universities with companies and factories; encouraging the companies to participate in joint research, coordinating to improve the quality of training engineers in accordance with their professional. Accordingly, the universitiescan, on the one hand, receive funding or sponsorship from industrial sectorswith technology research need or talent training; on the other hand, create a good internship environment for the students, receive the new knowledge from real findings, making the training and research process richer and more practical.

In fact, the universities in Japan focus on promoting academic and research connection with production, linking universities with the enterprises, accordingly, the enterprises, universities and the Ministry of Education and Science or the city contribute capital to build business nurseries, hi-tech zones. As a result, thousands of such projects have been implemented: The imaging diagnosis project in the field of health is carried out by Canon Inc. in collaboration with Kyoto University to invent modern technologies for early diagnosis of dangerous diseases, thereby reducing treatment costs and medical burdens for the society, in accordance with the policy of the Government [TranHau, 2012; p.160].

Keio University is the first private university established in 1858 and is one of the most prestigious universities in Japan, focusing on cooperation with the enterprises on research and transferof technology. In the total budget for Keio's research of nearly 16 billion yen in 2006, about $61.4 \%$ was supported by central government, local government and other government agencies and $29.5 \%$ was supported from private company [NguyenMinhPhuong, 2012; p.178].

\subsection{Lessons from the Socialization of Higher Education in Vietnam: A Philosophical Perspective}

Policies to mobilize resources for education and training in countries, which are often in an open and dynamic trend. In addition to the state budget, a regime of fee collection is suitable to each subject, 
encouraging and allowing the attraction of all contributions from social classes, socio-economic organizations and donors as well as international organizations. Thanks to these diverse sources of revenue, the education sector has actively implemented diversification of training types.

Private education in higher education has recently been a new trend with a relatively fast growth worldwide for the last few decades. However, in fact, the privatization in education is very diverse, depending on the specific circumstances as well as the policy choices of each country, depending on each development period. Currently, in Asia, the students at private schools account for the majority in Taiwan, India, Indonexia..., especially a country can account for $80 \%$. This phenomenon called "Japanese models" which has spread to Taiwan, South Korea. India and Indonesia did not have a private university system until the 2000s, but until now there have been about $50 \%$ of students enrolled in the private schools [PhamThu $]^{1}$

The higher education systems of the countries in the study show that, in the field of education, if we take the common goal into account, there is not significant differences between privatization trend in the world, these countries and the educational socialization in Vietnam. However, if going into the goals as well as specific solutions, a relatively large difference can be found. The Government of Vietnam has determined that the goal of educational socialization is "To create conditions for the whole society, especially beneficiaries of social welfare, the poor who have opportunities to be entitled the educational achievements ... at an increasingly high level". [Communist party Vietnam, 1991; p.38], at the same time, determined "To promote the intellectual and material potential of the people, as well as to mobilize the whole society to take care of health issues"[Nguyen Phu Trong, 2006; p.522]. Although the concepts and methods of attracting social resources for educational development differs due to the specific socio-economic conditions of each country, the experiences of other countries in mobilizing the participation of organizations, individuals and society for the development of education, which can provide useful experiences.

Firstly, ensuring the necessary financial resources for public education at the basic education levels. The finance for public education hereby is understood as financing for the school established by the State but can still include: state budget, tuition and community contributions. Due to the different characteristics, it is necessary to apply the general principle that 'universal education' is completely free, except for some private institutions with high tuition fees and high quality for children of welloff families. For higher education and vocational training, beneficiaries of education and the community must basically contribute, however, the State has a policy of scholarships, tuition waivers, reduction and a student loan fund so as to ensure the social justice.

For higher education, increasing the proportion of "private finance" in public institutions as well as expanding private universities, which is a common solution in many countries. A private university established by the State, which is "privately operated but publicly funded" as in Singapore. Of course, the private school is not for profit purpose, because there is always a "Board of Trustees" composed of the majority of people outside the school, representing the interests of the community and society. It is a form of "providing private education services" but "public funding".

The state usually provides budget for education in the direction of "grant by task completion index", or direct allocation to students; ensure the state budget for public higher education in a "cost-sharing" manner of about 30 to $40 \%$, depending on each specific case.

Secondly, mobilizing the participation of communities for intellectual and effort perspective, so as to improve the quality and efficiency of educational services. Most of higher education institutions have the board of trustees, in which the members represent groups with "related interests" implementing the effective, transparent and accountable governance. At the same time, it is also the basis for mobilising the participation of the community in the school's activities. In higher education, the network will be a "part-time" teaching staff, including the experts from the business community, government agencies, intellectuals being overseas compatriots and even teachers retired but still in good health and condition and so on (may account for 30 to $40 \%$ of the total number of lecturers at public universities and 40 to $50 \%$ at private universities).

${ }^{1}$ Pham Thu, 2012, South Korea's smart education strategy, see https://www.nhandan.com.vn/thegioi/item/1935 9702-.html 
Thirdly, mobilising the participation of the community and businesses in the development of private higher education. Although the education system is always state-owned in most countries of the world, the private education sector is tending to grow more and more strongly. It mainly develops the private form of "a half of for-profits" and training institutions of big companies; building criteria and the process of establishing schools when they fully meet those criteria and so on. At the same time, the State has policies to encourage the construction of human resource training funds and organize the training and fostering at the enterprises.

Experience of the countries in the study shows that the content of the training program is designed to meet the development needs of the economy in general and the enterprises in particular. As a result, the enterprises have the form of university support through activities of granting scholarships to students, paying tuition fees in the form of university grants, in order to train, provide human resources for the enterprises, provide the finance for the universities through signing research, consulting and venture capital contracts (inventions, new ideas, and so on). On the other hand, the enterprises can make financial contributions to the universities to set up companies, business incubators and high-tech parks.

Financial management at the universities is like a enterprise, allowing public universities to establish for-profit companies, including "public-private link", which have right to issue bonds, borrow beneficial capital, lease the unused temporary assets, expand research and service activities, so as to ensure community contribution of about $20-25 \%$ in cost sharing. Exemption of corporate and personal income tax from the educational grant that builds up the capital support at the higher education institutions.

Fourthly, non-public education is an inseparable part of national education, especially higher education, which is required to mechanisms to encourage and support the development of non-public educational institutions; simultaneously; and promptly handle violations of the State's educational standards, ensuring the interests of the students. Developing non-public educational institutions is not only to increase the contribution of families, enterprises, communities and society to the educational services, but also to ensure the right to participate in the provision of educational services of each organization and individual as well as to meet the learning needs of all citizens, at the same time, to create a link between the training institutions and the human resource market. However, one of the basic conditions for the development of non-public educational institutions is to have a system of clear, comprehensive and uniform regulations on state education standards and sanctions strictly handling the manifestations of violations.

Fifthly, building the loan funds to create conditions for expanding the scope of higher education, at the same time, ensuring the access ability to higher education for the poor and the subjects having difficult economic conditions. In the countries stated in this study, most have changed from the "high tuition - numerous fundings" policy to the main trend of the student loan program that helps them pay for the tuition and a portion of the living expenses. In these countries, the income control is fairly difficult, so the student loan programs are mainly in the form of "fixed loans", the loans and repayments have been determined in advance. In particular, with the goal of increasing access to the poor, the student loan programs often have "hidden fundings" from the state through the low interest rate policy.

\section{CONCLUSION}

Most of the Asian countries as stated in the study, the school education are provided free of charge by the state and sponsor all children of school age. Although they are private schools, they are in fact partially financially supported by the state in various forms. For higher education, the increase in the proportion of "private financing" in public institutions as well as the expansion of private universities, which is considered a popular solution in the course of educational socialization. Besides, these are considered useful suggestions for the course of higher education socialization in our country in the current period.

\section{REFERENCES}

[1] Communist party Vietnam, Strategy of socio-economic stability and development till 2000. Publisher truth, 1991. Hanoi. 
[2] Communist Party of Vietnam, Document of the 8th National Congress, National Political Publishing House, 1996. Hanoi

[3] Communist Party of Vietnam, Document of the 9th National Congress, National Political Publishing House, 2001. Hanoi

[4] Communist Party of Vietnam, Document of the 10th National Congress, National Political Publishing House, 2006. Hanoi

[5] Communist Party of Vietnam, Document of the 11th National Congress, National Political Publishing House. 2011. Hanoi

[6] Tran Hau, Đoan Minh Huan, Developing social services in our country until 2020- Some theoretical and practical issues. National political publishing house, 2012. Hanoi.

[7] Nguyen Van Manh, The State's role in social development and social development management in the renovation process in Vietnam. National political publishing house, 2011. Hanoi.

[8] Nguyen Minh Phuon, Promote education and health society in Vietnam, National political publishing house, 2012. Hanoi.

[9] Kai Hong Phua, Health care financing options: lessons and innovations from the Singapore system, Singapore. 2003.

[10] Truong Thi Thanh Quy, responsibilities of the State and social organizations in socialization of health, 2017. Vol 15, n.09, p.13-21.

[11] Janet Tay, 2001, Public service reforms in Singapore. Singapore.

[12] Nguyen Phu Trong, National delegates' conferences and Central Executive Committee of the Communist Party of Vietnam (1930-2006]. National political publishing house, 2006. Hanoi.

[13] Pham Thu, 2012, South Korea's smart education strategy see https://www.nhandan.com.vn/thegioi/item/ 19359702-.html, update on November 22th, 2012.

[14] Vietnam Academy of Educational Sciences, Experience of a number of countries in developing education and training, science and technology associated with building intellectual staff. 2008. National Political Publishing House, Hanoi

\section{AUTHORS' BIOGRAPHY}

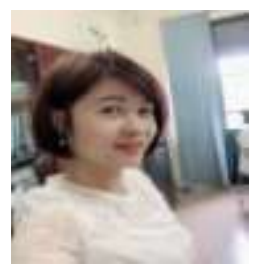

Truong Thi Thanh Quy, PhD, was born in 1976 in Vietnam. Doctor of Philosophy, Hanoi Medical University, Vietnam. Areas of study: Human development, human rights, social security, education, health and environment.

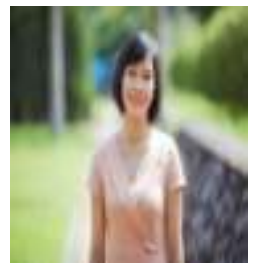

Duong Thi Nhan, $\mathrm{PhD}$, was born in 1987 in Vietnam. Doctor of Philosophy, Thainguyen University of Technology, Vietnam. Areas of study: education ideology Japan, the crisis of value in education, education Vietnam.

Citation: Truong Thi Thanh Quy, Duong Nhan. "Socializing Higher Education in a Number of Asian Countries and Lessons for Vietnam from a Philosophical Perspective". International Journal of Humanities Social Sciences and Education (IJHSSE), vol. 6, no.11, 2019, pp. 69-73. doi: http://dx.doi.org/10.20431/23490381.0611010 .

Copyright: (C) 2019 Authors. This is an open-access article distributed under the terms of the Creative Commons Attribution License, which permits unrestricted use, distribution, and reproduction in any medium, provided the original author and source are credited. 